\title{
Mineral profile exploratory analysis for rice grains traceability
}

\author{
Camila Neves Lange ${ }^{a, *}$, Lucilena Rebelo Monteiro ${ }^{\mathrm{b}}$, Bruna Moreira Freire ${ }^{\mathrm{a}}$, \\ Daniel Fernandez Franco ${ }^{c}$, Rogerio Oliveira de Souza ${ }^{\mathrm{d}}$, Cecilia Sacramento dos Reis Ferreira ${ }^{\mathrm{e}}$, \\ Julio José Centeno da Silva ${ }^{c}$, Bruno Lemos Batista ${ }^{a}$ \\ ${ }^{a}$ Centro de Ciências Naturais e Humanas, Universidade Federal do ABC, Rua Santa Adélia 166, Vila São Pedro, Santo Andre, SP, Brazil \\ ${ }^{\mathrm{b}}$ Centro de Quimica e Meio Ambiente, Ipen/CNEN-SP - Instituto de Pesquisas Energeticas e Nucleares/Comissao Nacional de Energia Nuclear, Av. Lineu Prestes, 2242 Sao \\ Paulo, SP, Brazil \\ ${ }^{\mathrm{c}}$ Centro de Pesquisa Agropecuária de Clima Temperado, Estação Experimental Terras Baixas, Campus Universitário, Embrapa - Empresa Brasileira de Pesquisa \\ Agropecuária, Pelotas, RS, Brazil \\ ${ }^{\mathrm{d}}$ Faculdade de Agronomia Eliseu Maciel - Departamento de Solos, Universidade Federal de Pelotas, Campus Universitário S/No, Sítio São Marcos, Pelotas, RS, Brazil

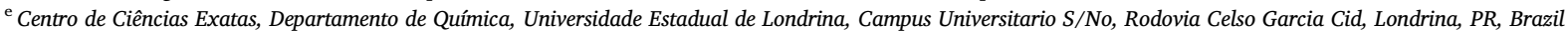

\section{A R T I C L E I N F O}

\section{Keywords:}

Brazilian rice

Arsenic species

Principal component analysis

Geographical discrimination

Rice traceability

\begin{abstract}
A B S T R A C T
Rice geographical traceability requires analytical procedures and data evaluation capable of linking its composition to the producing area. In this work, major and trace elements in soil and rice grains and husk from 9 cities and 17 producers were evaluated. Arsenic species were measured solely in rice grains. The rice mineral profile evaluated by principal component analysis allowed the identification of controlling variables and origin fingerprints. Vectors controlling data variability were linked to the geographical area, to crop management, producers and in a lower extent to soil composition. Elemental discrimination through 3D models was proposed. Arsenic species in the grains and elemental husk composition were decisive to achieve the required discrimination. Rice discrimination was obtained by cities, producers and varieties. The present work model was compared with others from similar studies.
\end{abstract}

\section{Introduction}

Rice is one of the most consumed cereals in the world (FAO, 2018). Worldwide consumers are becoming more aware of food safety and intrinsic product characteristics, such as traceability, the guarantee of origin, and quality certificates (Arisseto-Bragotto, Feltes, \& Block, 2017). Rice elemental composition is influenced by environmental and genetic factors (Kelly et al., 2002; Kokot \& Phuong, 1999; Kumarathilaka, Seneweera, Bundschuh, \& Meharg, 2018; Tuli, Chakrabarty, Trivedi, \& Tripathi, 2010). Soil composition, crop management, season variability can influence elemental and isotopic content in rice grain. Therefore, it is necessary to go beyond chemistry and geochemistry of rice crop to understand how the elemental content is finally expressed.

In 2017, Brazil produced circa 12 million tons of rice. Rio Grande do Sul state was responsible for $60 \%$ of this production (SOSBAI, 2010), mostly by flooding irrigation (IBGE, 2017). South Region of Brazil has a complex rice production chain, which is formed by crop production industries, rice producers, storage and drying, processing, wholesaler, retailer, and consumer. The processing food companies receive grains of rice from several producers. Meaning the rice commercialized by one producer may be cultivated in different regions. Further, the rice from the same producer may sometimes present different elemental signatures, due to the characteristics of the soil where it has been grown. In a matter of production traceability, to know the origin of the grains allows the correct nutritional labeling, crop control and mitigation of potentially toxic elements, such as $\mathrm{As}, \mathrm{Cd}, \mathrm{Pb}$, and other.

The mineral content and chemometric pattern recognition have been used as an important tool for the discrimination of the source or geographical origin of food (Cheajesadagul, Arnaudguilhem, Shiowatana, Siripinyanond, \& Szpunar, 2013), as metal content is generally stable. Once the sampling was carried out, sample preparation is simple and, therefore, multielemental determinations can be obtained by using atomic spectrometric techniques (Paniz et al., 2018).

According to Callao and Ruisánchez (2018), the exploratory analysis provides information about the relationship between samples, variables, and/or both. Principal components analysis (PCA) is a wellknown technique of exploratory analysis and generates new variables as

\footnotetext{
* Corresponding author.

E-mail addresses: camila.lange@ufabc.edu.br (C.N. Lange), luciremo@uol.com.br (L.R. Monteiro), bruna.freire@ufabc.edu.br (B.M. Freire), daniel.franco@embrapa.br (D.F. Franco), rosousa@ufpel.edu.br (R.O.de Souza), bruno.lemos@ufabc.edu.br (B.L. Batista).
} 
a linear combination of the original variables, which associates maximum information from the original data.

In one hand, other countries such as Taiwan (Wang, Hsu, \& Lu, 2011), Spain (Gonzálvez, Armenta, \& Guardia, 2011), Thailand (Kukusamude \& Kongsri, 2018) and Italy (Brandolini et al., 2006) traceability of rice is under development, and for some kinds of rice, it has already been adopted. On the other hand, few studies were developed in Brazil (Borges, Gelinsky, Souza, Barbosa, \& Batista, 2015; Kato, Fernandes, Bacchi, \& Sarriés, 2018; Maione, Batista, Campiglia, Barbosa, \& Barbosa, 2016). In all these studies, PCA proved to be a suitable tool to identify geographical origin (Brandolini et al., 2006; Cheajesadagul et al., 2013; Chung, Kim, Lee, \& Kim, 2015), to discriminate organic and conventional grains (Borges et al., 2015; Brandolini et al., 2006), to find association maps of rice physiological disorders (Agrama \& Yan, 2009).

In this scenario, the present study aimed to evaluate the main elemental content in 35 soils and 70 rice grains and husk samples from producers of the state of Rio Grande do Sul, Brazil. Inorganic and organic As content were also determined in the grains The potentially toxic elements (PTE) content of rice grains were compared with national and international regulations. Moreover, PCA was applied in order to i) evaluate how the rice elemental composition was affected by soil, ii) investigate the husk influence on rice discrimination and iii) establish which parameters could be used for rice geographical discrimination in a rice producing area of approximately $20 \mathrm{~km}^{2}$.

\section{Hypothesis}

Soil, rice grain, and husk mineral profile can provide a set of variables capable of rice geographical discrimination.

\section{Material and methods}

\subsection{Rice sampling}

Seventy rice samples were provided by 17 producers from 9 cities in the state of Rio Grande do Sul, in the southern Brazilian region, as presented in Table S1. Fig. 1 shows the cities included in this study. Itaqui is the most dislocated city from Pelotas producing area. All the other remaining cities are located in an approximated area of $20 \mathrm{~km}^{2}$ around Pelotas. Most samples came from Pelotas $(n=49)$, Arroio Grande $(n=30)$, and Santa Vitoria do Palmar $(n=28)$. The sample group included Puita $(n=96)$, Irga $424(n=38)$, and Puitainha CL $(\mathrm{n}=2)$ varieties.

\subsection{Soil sampling and characterization}

A total of 35 topsoils $(0-20 \mathrm{~cm})$ samples were collected in the region of the study (Fig. 1). Soil samples were disaggregated and air dried at room temperature and, then, sieved using a $2 \mathrm{~mm}$ nylon-mesh, homogenized and packed in polyethylene bags. These samples were characterized for particle size, $\mathrm{pH}\left(\mathrm{H}_{2} \mathrm{O}\right)$, total acidity $(\mathrm{H}+\mathrm{Al})$, available $\mathrm{P}$ and $\mathrm{K}$, extractable $\mathrm{S}$, total nitrogen according to the procedures described by Tedesco, Gianello, Bissani, Bohnen, and Volkweiss (1995).

\subsection{Reagents and materials}

Deionized water (resistivity $18.2 \mathrm{M} \Omega \mathrm{cm}$ ) was used in all experiments (Gehaka, Master System All, SP, Brazil). All reagents and media used were of analytical grade, and all the solutions were stored in amber bottles at $-20^{\circ} \mathrm{C}$. Plastic bottles (Nalgene ${ }^{\circledR}$ ), vials and glassware were cleaned by soaking in $15 \%\left(\mathrm{v} \mathrm{v}^{-1}\right) \mathrm{HNO}_{3}$ for $24 \mathrm{~h}$, rinsed five times with deionized water and then, dried in class 100 laminar flow hood (Filter flux, Piracicaba, Brazil).

\subsection{Determination of major and trace elements in soil and rice}

For rice analysis, the husk was manually separated from the grain. Grains and husks samples were milled, sieved $(<250 \mu \mathrm{m})$ and homogenized. All samples (in triplicate) were weighted $(\sim 200 \mathrm{mg})$ in $50 \mathrm{~mL}$ conical tubes (Falcon Corning, Tamaulipas, Mexico), closed and predigested for $24 \mathrm{~h}$ with $2 \mathrm{~mL}$ of sub-boiled $\mathrm{HNO}_{3}$. Then, $1 \mathrm{~mL}$ of $\mathrm{H}_{2} \mathrm{O}_{2}+8 \mathrm{~mL}$ of deionized water were added, and the mixture was heated at $150{ }^{\circ} \mathrm{C}$ during $1 \mathrm{~h}$ in a microwave oven (Ethos Easy, Milestone, Italy). After cooling, the volume made up to $30 \mathrm{~mL}$ with deionized water and analyzed by ICP-MS (Paniz et al., 2018).

For soil analysis, the determination of chemical elements was based on U.S. EPA. 3051A extraction procedure (Suda \& Makino, 2016; USEPA, 2007), with some modifications according to Segura et al. (2016), as follows: $0.5 \mathrm{~g}$ of each sample was placed into Teflon vessel (Savillex, USA) containing $10 \mathrm{~mL}$ of sub-distilled $\mathrm{HNO}_{3}$ and closed. After, the vessels were heated at $175^{\circ} \mathrm{C}$ in a digestion block during 5 min (EasyDigest ${ }^{\circledast}$, Analab, France). After cooling, the volume made up to $50 \mathrm{~mL}$ with deionized water and analyzed by ICP-MS and then, 5 -fold diluted and analyzed by ICP-MS (ICP-MS Agilent7900, Hachioji, Japan).

\subsection{Sample preparation for quantification of total and species of As}

Arsenic speciation was performed according to the procedure described by Batista, Souza, Souza, and Barbosa (2011). The As extraction procedure was performed by adding $10 \mathrm{~mL}$ of $0.28 \mathrm{~mol} \mathrm{~L}^{-1} \mathrm{HNO}_{3}$ to $200 \mathrm{mg}$ of sample and then heated in a water bath (Solab, Sab, S3) to $200 \mathrm{mg}$ of sample and then heated in a water bath (Solailtered on a cellulose filter $(0.2 \mathrm{~mm}$, Sartorius, Germany) and analyzed by HPLCICP-MS.

\subsection{Statistics}

PCA and statistical tests were performed using Statistica version 8.0 from Stat Soft (Tulsa, OK, USA). When the number of samples under each grouping variable (Cultivar, City, and Producer) allowed, F-test was applied to data. Usually, F-test is applied to identify if two groups of samples have or not equivalent variances. The $t$-test was used to compare averages and decide if they are statistically equal or not, assuming they have equivalent variances. These tests were used to verify if rice samples from Puita and IRGA424 cultivar have statistically similar mean and variances. Also, if grouped samples by city and by producer lead to statistically similar or different results.

To perform PCA, analytical variables were auto-scaled to correct differences in concentration range for each element. By that way, each variable had the same opportunity to be modeled (Bro \& Smilde, 2014). No difference in species or elemental concentration influence the variable contribution to the model (Bro \& Smilde, 2014).

Rice data set was composed of 70 duplicated samples $(n=140)$, where a total of 43 variables were analyzed. Three qualitative variables were used for sample classification (City, Producer, and Variety). Quantitative variables were measured in rice grains $(n=26)$ and rice husk $(\mathrm{n}=12)$. These variables were named as ". $g$ " and " $h$ " to designate rice grain and husk, respectively. After the first exploratory evaluation, non-discriminating elements and outlier samples were removed to improve PCA model.

Outlier removal was performed, and 140 cases were validated to principal component analysis. In most cases, outliers were removed due to missing variable values, and by exceeding sample replicate criteria. PCA was also applied to soil samples to understand the geochemical behavior of the studied area (Fig. 1). A matrix of 35 cases by 26 variables was evaluated to soil samples. Loading factors above 0.5 were considered. 


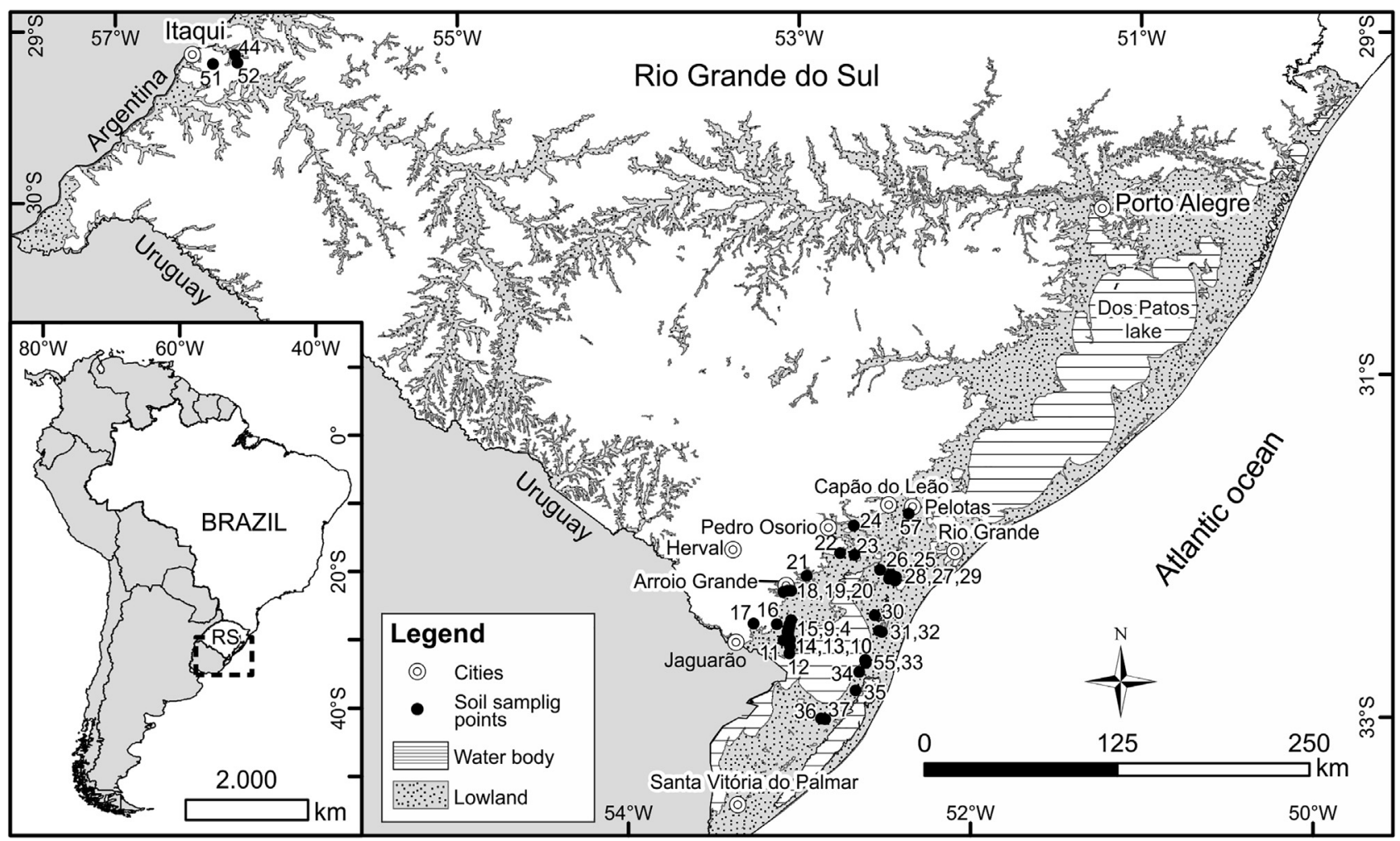

Fig. 1. Geographical location of the studied cities and soil sampling points.

\section{Results}

The statistical summary of $A s_{t o t}, \mathrm{As}_{\text {org }}$, As $s_{\text {inorg }}$, major and trace elements measured in rice grains and husk is presented at Table S2. Table S2 presents values by cultivar (Puita and Irga), as well as per quadrant separation obtained in the PC. Mean, standard deviation and number of samples in each group is presented by variety $(n=2)$, by city $(n=9)$ and by producer $(\mathrm{n}=17)$.

\subsection{Exploratory analysis on rice traceability}

The exploratory PCA was performed on a data matrix of 43 variables and 140 cases. Such large matrices are reduced to the main components that explain the variability of the whole group of samples. In this exploratory analysis, 8 principal components were found explaining $72.7 \%$ of all matrix variability (Table S3).

\subsubsection{By variables}

A summary of the elemental association in rice by principal component is presented in Table 1. Factor 1 (F1) explained $21.95 \%$ of the matrix variability. The correlated elements under F1 resume more substantial effects on the data matrix than the remaining ones. A positive correlation was observed between $\mathrm{Mn}$ (Loading $>0.9$ ), $\mathrm{Ni}, \mathrm{Cu}$, $\mathrm{Ba}(>0.8)$, and $\mathrm{Fe}(>0.5)$ in grains and $\mathrm{Ba}, \mathrm{Co}(>0.7)$ and $\mathrm{Mn}(>0.5)$ in the husk. This factor also presented a negative correlation with $\mathrm{As}_{\text {tot }}$, $\mathrm{As}_{\text {org }}(<-0.7)$, As inorg $_{\text {, }} \mathrm{Na}, \mathrm{Sr}(<-0.5)$ in grain and $\mathrm{As}_{\text {tot }}(<-0.5)$ in husk samples. Magnesium present in the husk had a correlation value, close enough to be included in the association ellipse (0.5) with As species, as presented in Fig. 2A. These elements were responsible for the samples separation and clustering observed on case plot.

An inverse correlation observed between elements of F1 could be linked to changes in the elemental uptake. In the husk, exchanges of $\mathrm{Mg}$ and As by Mn, Ba and Co could occur. In the rice grain, exchanges of As species, $\mathrm{Na}$ and $\mathrm{Sr}$ by $\mathrm{Mn}, \mathrm{Cu}, \mathrm{Ba}$, and $\mathrm{Ni}$ are also possible (See Fig. 2A).

Factor 2 associated with strong positive correlation $\mathrm{Mg}, \mathrm{P}$, and $\mathrm{K}$ (approximately 0.8 ) in grain and with good correlation $\mathrm{B}, \mathrm{Na}$, and $\mathrm{Fe}$ $(>0.5)$ in grain. Factor 2 covered only elements present in rice grain with $12.16 \%$ of matrix variability.

Factor 3 associated elements such as $\mathrm{Zn}(>0.7) \mathrm{Cu}, \mathrm{Ni}, \mathrm{Mg}$, and $\mathrm{Mn}$ $\left(>0.5\right.$ ) in rice husk. Important variables such as $\mathrm{As}_{t o t}, \mathrm{Cd}, \mathrm{Pb}$, and $\mathrm{Fe}$ also measured in husk showed correlation values around 0.5 . Therefore, these elements were separated from the core and included in the association ellipse, as presented in Fig. 2B. Factor 3 associated only elements present in the husk, therefore $10.31 \%$ of all matrix variability was linked to husk conditions.

Some of the elements that did not contribute clearly to explain the matrix variability were $\mathrm{Cr}, \mathrm{Zn}, \mathrm{Cd}, \mathrm{Sb}, \mathrm{Pb}$ and $\mathrm{Bi}$ in the grain and $\mathrm{Fe}, \mathrm{Se}$, $\mathrm{Cd}$, and $\mathrm{Pb}$ in the husk. However, only Se in the husk could be excluded from Factor 3 (loading values $\ll 0.5$ ). This fact could reflect a local trend, and these elements could be important to discriminate samples from other geographical areas with different soil composition.

\subsubsection{By cases}

Fig. 2C and D presents samples mean centered distribution by factors according to the city and to the variety. Then, one of the easiest ways to evaluate the discrimination power is by the case distribution on each quadrant of the score plot (Bro \& Smilde, 2014). The farther samples are from the axis center $(x, y=0,0)$ coordinates and the closest from each other, the easiest will be the group discrimination. Then, the geographical distribution was partially discriminated by quadrants (see also Table S2). Samples from Pelotas were concentrated in 1st and 4th quadrants on F1 $\times$ F2 score plot. Samples from Santa Vitoria do Palmar and from Arroio Grande were most frequently observed in 2nd and 3rd quadrants respectively. In 1st and 4th quadrants, $86 \%$ of cases were originated in Pelotas. When higher loading values of Factor 1 were considered (F1 $\geq 3$ ), all identified samples $(n=27)$ were from Pelotas and producer P1.

In the 2nd quadrant of F1XF3 (Fig. 2D), 48\% of samples were from Santa Vitoria do Palmar, and $21 \%$ were from Pelotas. While in 3rd quadrant, $58 \%$ of samples were from Arroio Grande and $15 \%$ from 
Table 1

Principal components loading summary from rice grain and husk.

\begin{tabular}{|c|c|c|c|c|c|c|}
\hline \multirow[t]{2}{*}{ Factor } & \multirow[t]{2}{*}{$\%$ variance } & \multicolumn{2}{|c|}{ Positive Correlation } & \multicolumn{2}{|c|}{ Inverse Correlation } & \multirow[t]{2}{*}{ Evaluation } \\
\hline & & High & Low & High & Low & \\
\hline \multicolumn{7}{|l|}{ Grain } \\
\hline PC1 & 21.95 & $\begin{array}{l}\mathrm{Ba}, \mathrm{Mn}, \mathrm{Ni} \\
\mathrm{Cu},\end{array}$ & $\mathrm{Fe}$ & $\begin{array}{l}\text { As } \\
\text { As } \\
\text { org }\end{array}$ & $\begin{array}{l}\mathrm{As}_{\text {inorg }}, \mathrm{Na}, \\
\mathrm{Sr}\end{array}$ & $\begin{array}{l}\text { As is known to interfere in nutrient uptake and distribution in the plant. PC1 seems to be } \\
\text { linked to this effect. Presence of Fe, Mn and As in this factor suggests influence of redox } \\
\text { conditions }\end{array}$ \\
\hline PC2 & 12.16 & Mg, P, K & $\mathrm{Na}, \mathrm{B}, \mathrm{Fe}$ & - & - & $\begin{array}{l}\text { Related to main plant nutrients. PC } 2 \text { could be linked with fertilizers and crop management. } \\
\text { Almost a component discriminated by grain effects }\end{array}$ \\
\hline PC3 & 10.31 & - & - & - & - & No contribution from the grain \\
\hline \multicolumn{7}{|l|}{ Husk } \\
\hline PC1 & 21.95 & Ba, Co & Mn, Mg & - & $A s_{\text {tot }}$ & Same as PC1 for grain components \\
\hline PC2 & 12.16 & - & $\mathrm{Mg}, \mathrm{Ni}$ & - & - & Almost no contribution on the husk \\
\hline PC3 & 10.31 & $\mathrm{Zn}$ & $\begin{array}{l}\mathrm{Cu}, \mathrm{Mn}, \mathrm{Mg}, \mathrm{Ni} \\
\mathrm{Pb}, \mathrm{Cd}, \mathrm{Fe}\end{array}$ & - & - & $\begin{array}{l}\text { Exclusively discriminated by elements from husk } \\
\text { PC } 3 \text { could be linked with soil due to PTE presence }\end{array}$ \\
\hline
\end{tabular}

Bold elements are present at the same PC for Grain and husk.
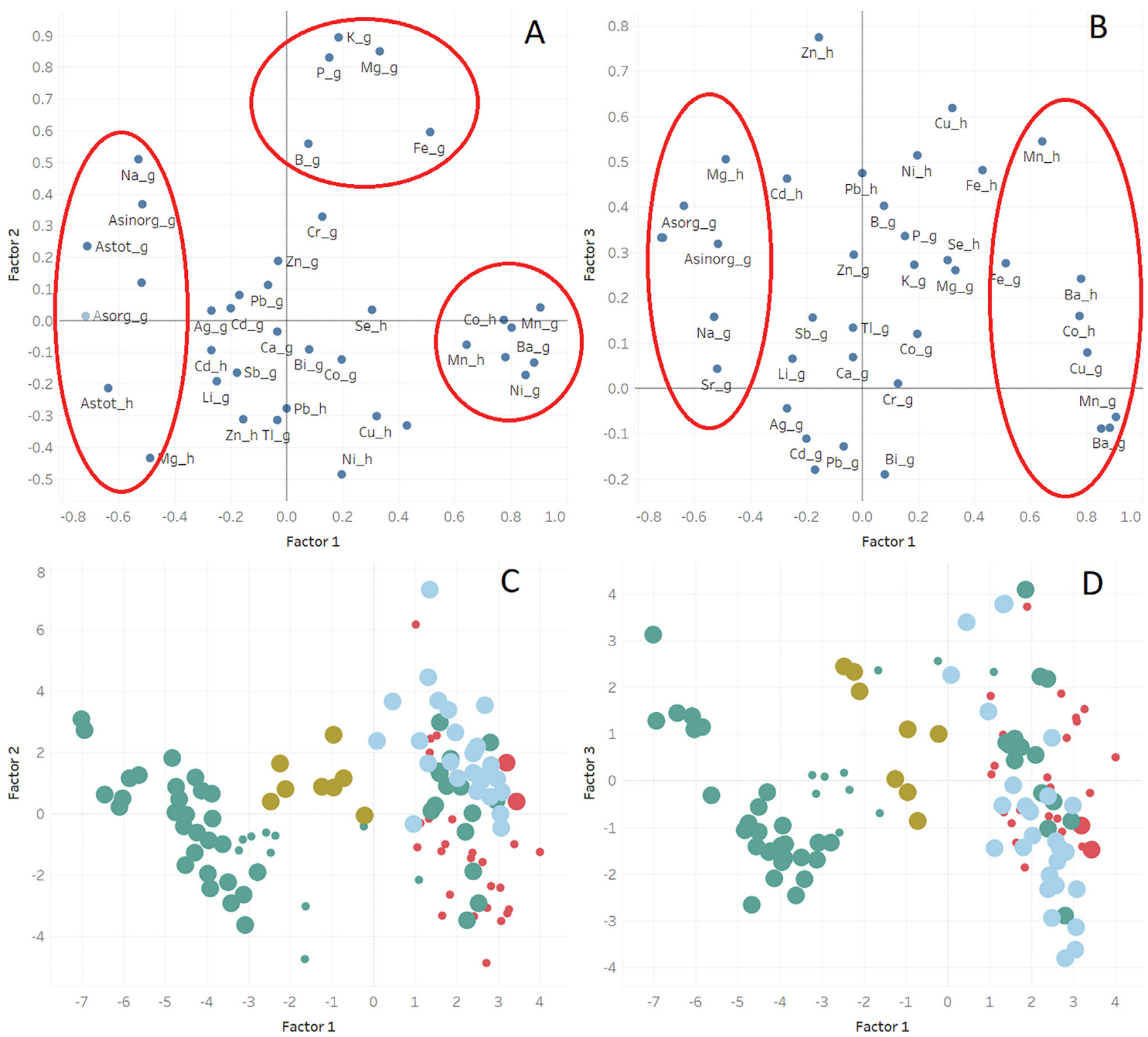

Fig. 2. Principal component analysis with (A) Factor 1 versus Factor 2 and (B) Factor 1 versus Factor 3 loading plots by elements; (C) Factor 1 versus Factor 2 and (D) Factor 1 versus Factor 3 loading plots by cities. Cities: Arroi grande (light blue); Itaqui (brown); Pelotas (green); Santa Vitória do Palmar (red). (For interpretation of the references to colour in this figure legend, the reader is referred to the web version of this article.) 
Pelotas. Regarding geographical discrimination, these percentages could seem not enough; however, all cities but Itaqui are in the same geological formation (Althaus et al., 2018). Distance between Arroio Grande and Pelotas is $96 \mathrm{~km}$. Therefore, the main effect of discriminating rice between these cities is related to crop management and producers' practices.

A small cluster that concentrated samples from Itaqui was also observed linked to lower positive values of F1 and F3 ( $0 \leq$ Factor $1 \leq 2$ and $0 \leq$ Factor $3 \leq 4$ ) as observed in Fig. 2C. Itaqui samples were discriminated by the high content of $\mathrm{Zn}$ in the husk.

First and 4th quadrants grouped samples with lower As tot $_{\text {values, }}$ that seems to be the signature of samples from Pelotas and Itaqui. While 2nd and 3rd quadrant corresponded to samples with higher As stot $_{\text {values, }}$ those correspond to samples from Arroio Grande, and Santa Vitoria do Palmar.

At the same time, that factor 2 discriminate samples by its content of $\mathrm{Mg}, \mathrm{P}$, and K. Then, Santa Vitoria do Palmar, Itaqui and some samples from Pelotas were placed in 3rd and 4th quadrants due to the lower values of these elements.

Some samples of Irga 424 variety were discriminated from others by factor 4 (Factor $4 \geq 2$ ) as presented in Fig. S1. The discrimination was associated with high Co content samples with higher $\mathrm{As}_{\text {tot }}$ values, those correspond to samples from Arroio Grande, and Santa Vitoria do Palmar.

At the same time, that factor 2 discriminate samples by its content of $\mathrm{Mg}$, P, and K. Then, Santa Vitoria do Palmar, Itaqui and some samples from Pelotas were placed in 3rd and 4th quadrants due to the lower values of these elements.

Some samples of Irga 424 variety were discriminated from others by factor 4 (Factor $4 \geq 2$ ) as presented in Fig. S1. The discrimination was associated with high Co content.

\subsection{Soil results}

The data obtained on soil geochemical composition is reported in Table S4. In general, the Brazilian lowland soils have the following characteristics, considering agricultural recommendations for the irrigated rice crop (SOSBAI, 2010): low total organic carbon $\left(5.2-28 \mathrm{~g} \mathrm{~kg}^{-1}\right)$, clay $\left(36.1-510 \mathrm{~g} \mathrm{~kg}^{-1}\right)$ and nitrogen contents $\left(0.61-3.2 \mathrm{~g} \mathrm{~kg}^{-1}\right)$. Most of the samples presented $\mathrm{pH}$ bellow to the 5.5 recommended value (SOSBAI, 2010). The $\mathrm{pH}$ ranged from 4.4 to 6.6 with very low $\mathrm{H}+\mathrm{Al}$ content ranging from 1.19 to $9.75 \mathrm{cmol}_{c} \mathrm{dm}^{-3}$ and also low potassium levels $\left(0.050-0.75 \mathrm{cmol}_{c} \mathrm{dm}^{-3}\right)$; high calcium $\left(0.7-20.4 \mathrm{cmol}_{c} \mathrm{dm}^{-3}\right)$, magnesium $\left(0.20-8.3 \mathrm{cmol}_{c} \mathrm{dm}^{-3}\right)$ availability; wide variability of $\mathrm{S}_{-} \mathrm{SO}_{4}{ }^{2-}\left(4.05-61.3 \mathrm{mg} \mathrm{dm}^{-3}\right)$, available phosphorus (2.84-40.1 $\mathrm{mg} \mathrm{dm}^{-3}$ ); and base saturation (2.07-93.7\%); and average $14.4 \mathrm{cmol}_{c} \mathrm{dm}^{-3}$ of CEC.

Overall, regarding potentially toxic elements (As, $\mathrm{Cd}, \mathrm{Co}, \mathrm{Cu}, \mathrm{Pb}$, and $\mathrm{Zn}$ ) content in the soil samples, the pseudo-total concentrations obtained were below the maximum limits for soil quality. The only exception was the Co concentration at sampling point 44 from Itaqui $\left(18.5 \mathrm{mg} \mathrm{kg}^{-1}\right)$, which was expected considering that this region has a distinct geological formation from the other points. Since the permissible Co concentrations for soil quality are $<13 \mathrm{mg} \mathrm{kg}^{-1}$ for quality reference, $25 \mathrm{mg} \mathrm{kg}^{-1}$ for prevention, and $35 \mathrm{mg} \mathrm{kg}^{-1}$ for the intervention of agricultural activity, this sampling point Co concentration can be classified as safe for agricultural purpose.

\subsubsection{Soil variables association}

The PCA of the soil data (26 variables $\times 35$ cases) had components that explained $84.3 \%$ of the total variance. Parameters with high covariance were linked and were interpreted by similar chemical behavior or process (Tables S5 and S6). With 49.4\% variability, Factor 1 indicated a positive correlation between $\mathrm{Na}_{\text {exc }}, \mathrm{Mg}_{\text {exc }}$ (Loading $>0.9$ ), $\mathrm{Ca}, \mathrm{Ca}_{e x c}, \mathrm{CEC}, \mathrm{Mg}, \mathrm{S}_{-} \mathrm{SO}_{4}{ }^{2-}(>0.8), \mathrm{Cd}, \mathrm{N}, \mathrm{Se}(>0.7), \mathrm{As} \mathrm{pH}_{w t}(>0.6)$, $\mathrm{K}_{\text {exc }}$ and Clay content $(>0.5)$ in lowland soils from Rio Grande do Sul. In this factor a very tight cluster of exchangeable elements ( $\mathrm{Ca}, \mathrm{Mg}, \mathrm{Na}$ and $\mathrm{S}^{-\mathrm{SO}_{4}}{ }^{2-}$ ) and $\mathrm{CEC}$ was observed, probably these elements had the same source. CEC is usually linked to different clay types and blends. Therefore it is very dependent on soil clay content and organic matter (Bini et al., 2014). Accounting for $16 \%$ of the total variability, F2 correlated $\mathrm{pH}_{(w t+s m p)}$, and base saturation directly and inversely $\mathrm{H}+\mathrm{Al}_{\text {exc }}$, Zn, P, Clay, $\mathrm{K}_{\text {exc }}$. Accounting for $13.4 \%$ of total variability, F3 showed the high loading factor for $\mathrm{Fe}, \mathrm{Mn}, \mathrm{Co}, \mathrm{Cu}$, and $\mathrm{Pb}$. With $5.5 \%$ of total variability, F4 linked $\mathrm{P}_{\text {aval }}$ and TOC, most probably linked to soil management practices. From mineral or organic fertilizers, $P$ helps to maintain and optimize crop production, and it has been widely applied in Brazil. Since in tropical and subtropical regions, $\mathrm{P}$ is low due to strong phosphate adsorption on mineral soils (Fink, Inda, Tiecher, \& Barrón, 2016). The soil data set had no clear discrimination by geographical region. Apart from Itaqui, all cities in the studied region belong to the same soil formation zone, which can explain no discrimination regarding the soil composition.

\subsection{Simplified discrimination model}

Samples from Pelotas were separated into two spatial regions. The first region, with low $\mathrm{As}_{\text {tot }}$ content, correspond to the space of samples
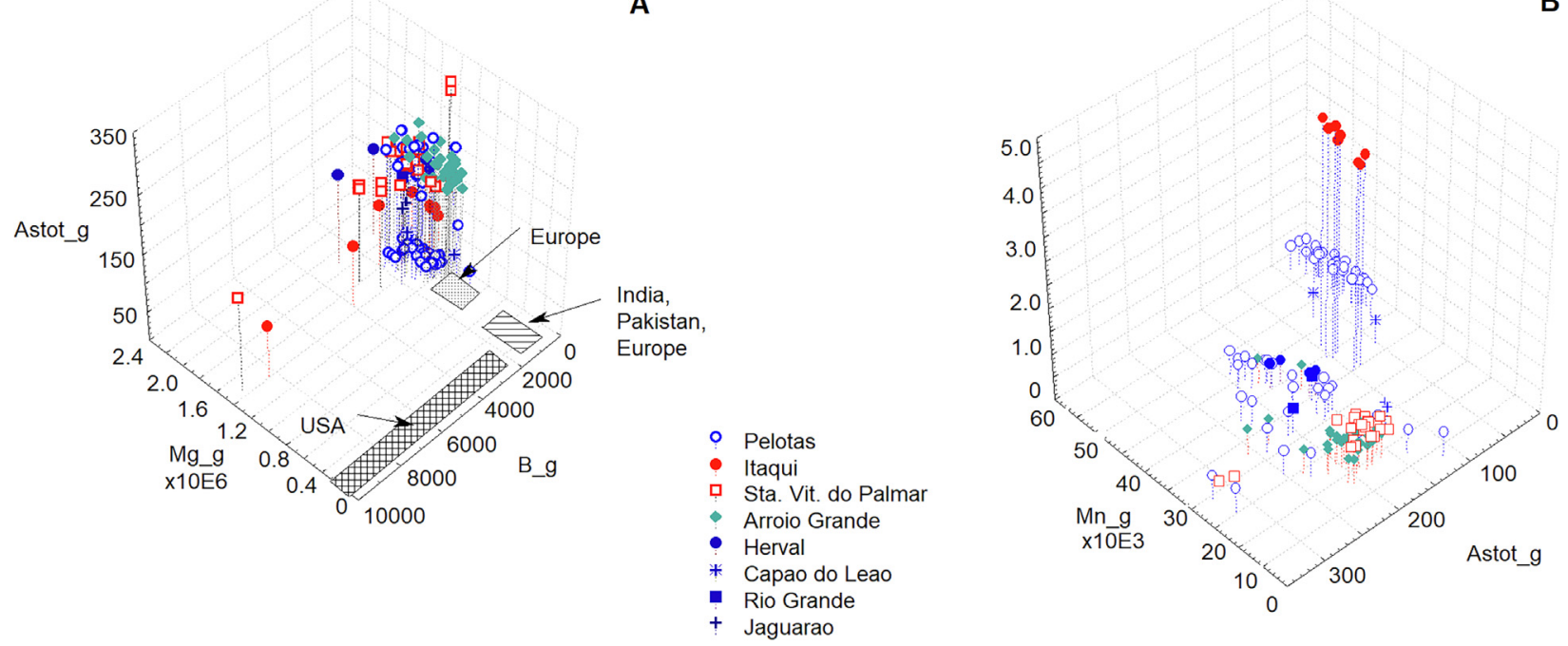

Fig. 3. Simplified 3D model of rice geographical discrimination. 


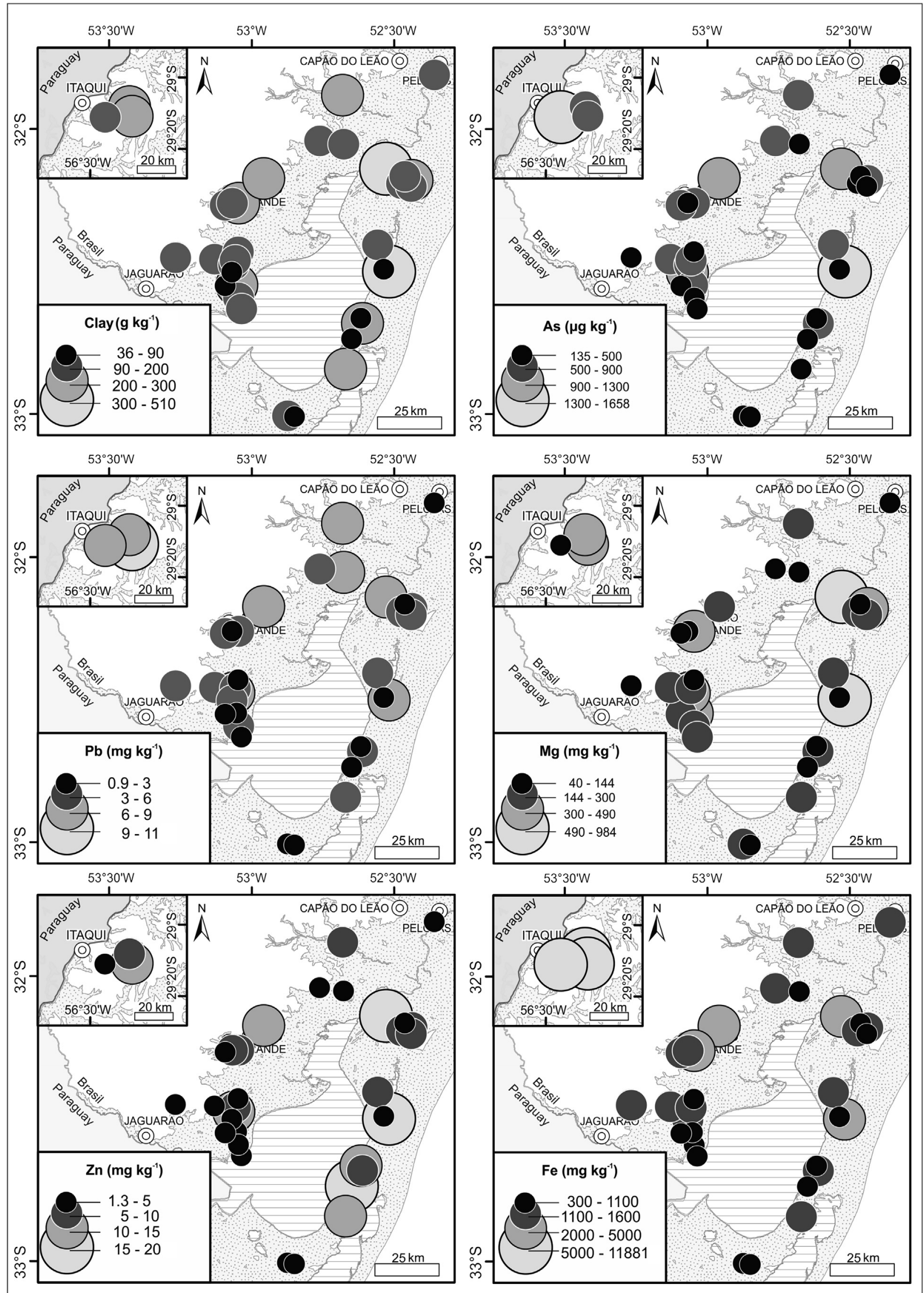

Fig. 4. Spatial distribution of soil composition. 
from producer P1. The remaining samples from Pelotas did not exhibit a distinct pattern. The rice from Santa Vitoria do Palmar and from Arroio Grande were very similar, in a 3D volume, very close to each other. However, a small degree of discrimination was found between samples from Santa Vitoria do Palmar and from Arroio Grande, as presented in Fig. 3, mainly due to $\mathrm{Mg}$ content in grain. Arroio Grande had smaller $\mathrm{Mg}$ and $\mathrm{Ni}$ values than samples from other cities. Samples from Santa Vitoria do Palmar and from Pelotas from different producers than P1 were mostly superposed.

\section{Discussion}

\subsection{PTEs content in rice grains}

The concentrations of As, $\mathrm{As}_{\text {inorg }}$, $\mathrm{Cd}$, and $\mathrm{Pb}$ in the husked grains of the present study were compared with the maximum levels of regulating agencies (ANVISA, 2013; Commission, 2016). All measured concentrations, except for $\mathrm{Pb}$ in 5 rice samples from a total of 140 (3.6\% of samples), complied with reference levels (See Table S7). Therefore, the rice from this region poses no concern for human health, considering these analytes content.

Usually, the content of $\mathrm{Cd}$ and As is related to the soil redox potential (Guo, Zhang, Wang, \& Shen, 2010). Where As is more available under reductive conditions and $\mathrm{Cd}$ requires more oxidant environment to be soluble. However, grain and husk PCA by variables did not indicate an evident opposite trend between As and Cd Fig. 2, as reported previously by Kokot and Phuong (1999).

\subsection{Geographical origin discrimination}

In this present study, 25 elements and $\mathrm{As}_{\text {org }}$ and $\mathrm{As}_{\text {inorg }}$ were measured in 70 rice grain, and husk samples from two varieties (IRGA424 and Puita) from nine different cities in the state of Rio Grande do Sul. The mean concentrations of major elements were similar from those obtained in previous studies of Brazilian rice (Borges et al., 2015; Kato et al., 2018). Inorganic composition and characterization of soil samples were also determined, and the obtained results were similar to previous studies results (Althaus et al., 2018).

The findings of the present study indicated that Pelotas, Arroio Grande, Itaqui, and Santa Vitoria do Palmar presented a distinct profile of elemental compositions in rice grain and husk. PCA results showed that there was some difference between the other studied regions. No discrimination was obtained among varieties, except IRGA424 variety in Pelotas region. Recently, Kato et al. (2018) reported a study of geographical discrimination of rice from 4 regions of the state of Rio Grande do Sul by determining 11 chemical elements (As, Br, Cd, Co, Cs, $\mathrm{Fe}, \mathrm{K}, \mathrm{Mo}, \mathrm{Na}, \mathrm{Rb}$ and $\mathrm{Zn}$ ) in 4 different varieties (IRGA424, IRGA424 RI, Guri Inta, Puita Inta). These authors concluded that As, Br, Co, Cs, $\mathrm{Na}, \mathrm{Rb}$, and $\mathrm{Zn}$ presented potential to be used to distinguish rice grains from different regions, while no discrimination was obtained amongst varieties.

The first hypothesis that rice grains mineral profile from the nine cities could be differentiated by the soil composition and properties of each city was only partly supported. After applying the PCA on soil samples, the results suggested that the measured elements and the soil characteristics determined were not considered as discriminating parameters within the soil sampling region.

In general soil characteristics play an important role on elements mobility and translocation to plant systems; however, no remarkable soil pattern that could distinguish a specific region/city with an evident influence on grain mineral profile was identified by the soil statistical approach. The majority of soils analyzed were collected from areas of similar geological formation, except Itaqui samples. Therefore, the geographical origin of soil samples was not discriminated by PCA. Although the soil and rice samples did not match temporally in this study, the elemental concentration was considered representative of the sampled areas. In a first attempt to assess the elemental associations in the soil-husk-grain system presented interesting trends identified by PCA of soil variables. Arsenic had high loading values in the PCA, independent if the data set was composed of soil or rice samples. Therefore, this element has a strong potential to discriminate the riceproducing region.

Arsenic soil spatial distribution (Fig. 4) was closely matched with the As rice grain and husk content, and therefore matched with the quadrant discrimination obtained by $\mathrm{F} 1 \times \mathrm{F} 2$ on the grain and husk PCA. Other authors reported the As discriminating power for rice origin (Cheajesadagul et al., 2013; Chung et al., 2018; Kato et al., 2018).

The geographical distribution of As was also similar to the clay and the Mg patterns (Fig. 4), as expected by the PCA association of these variables under factor 1 . The content of $\mathrm{Mg}$ plays an important role on the discrimination of rice grains (factor 2) and husks (factor 1), as reported in previously by several authors (Borges et al., 2015; Cheajesadagul et al., 2013; Chung et al., 2015, 2018; Kelly et al., 2002; Wang et al., 2011).

Our results highlighted the use of husk for rice origin discrimination. This observation is especially true considering the $\mathrm{Zn}$ content, which was one of the main elements of discriminating rice origin (factor 3). The $\mathrm{Zn}$ variability is probably linked to its distribution in the soilsampling region (Fig. 4). In soil statistical evaluation, an inverse correlated between $\mathrm{Zn}$ and soil $\mathrm{pH}$ was observed. This negative correlation indicates that $\mathrm{pH}$ could significantly affect the $\mathrm{Zn}$ distribution in the analyzed soils. Alloway (2008) reported the reactions of Zn sorption in primary or secondary minerals as $\mathrm{pH}-$ regulated. Then, slightly acid soils with high base saturation, phosphate content, highly weathered (e.g., tropical soils) and very prolonged waterlogging or flooding may lead to zinc deficiency in crops. Low zinc contents were detected in rice grains. In Table S2 Supplementary material, grain $\mathrm{Zn}$ mean concentrations by region were satisfactory $\left(21.3-27.7 \mathrm{mg} \mathrm{kg}^{-1}\right)$, compared to the recommended target of $28 \mathrm{mg} \mathrm{kg}^{-1}$ for human nutrition (Alloway, 2008).

Several studies of tropical soils have indicated that Fe oxyhydroxides are important soil components in the sorption of trace metals (John, 2007). This element is well-known to regulate different mechanisms of PTEs uptake by rice plants, especially As (Yamaguchi, Ohkura, Takahashi, Maejima, \& Arao, 2014). Associated with Mn, Co, and $\mathrm{Cu}, \mathrm{Fe}$ was one of the main elements to explain soil variability observed in factor 3 of soil PCA. The association of these elements is consistent with geochemical affinity. Husk and grain Fe content provided discriminating power to factor 3 and factor 2, respectively. Iron distribution on soil sampling region (Fig. 4) was very similar to As distribution.

Manganese and $\mathrm{Fe}$ oxides are capable of binding various cations. According to Suda and Makino (2016), in most cases, Pb is the most strongly bonded element, followed by $\mathrm{Cu}$. A strong affinity between soil $\mathrm{Mn} / \mathrm{Fe}$ oxides with As and $\mathrm{Cd}$ in soil was also reported. Lead in husk was significant for rice discrimination (factor 3). Lead geographical distribution was illustrated in Fig. 4.

\subsection{Discrimination between As species}

Considering the As species can be affected by a more complex scenario during rice production, the content of $\mathrm{As}_{\text {org }}$ and $\mathrm{As}_{\text {inorg }}$ were expected to contribute more significantly to samples discrimination. However, the similar behavior among studied cities could be related to a local pattern from the state of Rio Grande do Sul. Therefore, As species could have geographical discriminating power in other location. However, some interesting trends were identified. Among Puita samples, a clear correlation was observed between $\mathrm{As}_{\text {tot }}$ and $\mathrm{As}_{\text {org }}$ (Fig. S2 in Supplementary material). This correlation indicates that a significant amount of As in the sample is present in the organic form (approximately 50\%). Among Irga424 samples, As org no significant correlation to $\mathrm{As}_{\text {tot }}$ was present/clear (Fig. S3 Supplementary material). This trend was maintained to both varieties of all studied cities. The correlation 
Table 2

Discriminating elements found in origin and geographical identification studies of rice samples.

\begin{tabular}{|c|c|c|c|c|}
\hline Sample characteristics & Location (Countries, regions, etc.) & Discriminating elements & Source & Reference \\
\hline Asian rice & $\begin{array}{l}\text { Cambodia, China, Japan, Korea, } \\
\text { Philippines and Thailand }\end{array}$ & $\begin{array}{l}{ }^{34} \mathrm{~S}, \mathrm{Mn} \text { and } \mathrm{Mg} \\
\mathrm{K}, \mathrm{Mn}, \mathrm{Mg} \\
\mathrm{Se}, \mathrm{Cd}, \mathrm{Cu}, \mathrm{Zn} \\
\mathrm{As}, \mathrm{Ba}, \mathrm{Sr} \text {, }\end{array}$ & $\begin{array}{l}\text { Soil } \\
\text { Crop management }\end{array}$ & Chung et al. (2018) \\
\hline $\begin{array}{l}\text { Organic and conventional } \\
\text { cultivated rice }\end{array}$ & Several cities in 5 states in Brazil & $\mathrm{Ca}, \mathrm{Cd}, \mathrm{La}, \mathrm{Ce}$ & Fertilizers & Barbosa et al. (2016) \\
\hline $\begin{array}{l}\text { Organic and conventional } \\
\text { cultivated rice }\end{array}$ & Brazil & $\begin{array}{l}\mathrm{Ba}, \mathrm{Mn}, \mathrm{P}, \mathrm{Ca}, \mathrm{Rb} \\
\mathrm{Cd}, \mathrm{Co}, \mathrm{Cu} \\
\mathrm{Mg}, \mathrm{Ce}, \mathrm{La}\end{array}$ & $\begin{array}{l}\text { Fertilizers and soil } \\
\text { composition }\end{array}$ & Borges et al. (2015) \\
\hline Brown rice & $\begin{array}{l}\text { Korea (Suwon), China (Shanghai) and } \\
\text { Philippines (Los Banos) }\end{array}$ & $\begin{array}{l}\mathrm{K}, \mathrm{Mg} \\
\mathrm{Rb}, \mathrm{Cs} \\
\mathrm{Cu}, \mathrm{Ag}, \mathrm{Zn}, \mathrm{Cr}, \mathrm{Ca}, \mathrm{Ba}, \mathrm{Cd}, \mathrm{Bi}, \mathrm{Pb} \text {, } \\
\mathrm{In}, \mathrm{Mn}, \mathrm{Ni}\end{array}$ & $\begin{array}{l}\text { Fertilizer and crop } \\
\text { management } \\
\text { Sol conditions }\end{array}$ & Chung et al. (2015) \\
\hline Polished rice & $\begin{array}{l}\text { Thailand, France, Japan, Italy, India, } \\
\text { Pakistan }\end{array}$ & $\begin{array}{l}\mathrm{B}, \mathrm{Co}, \mathrm{Sr}, \mathrm{Mo}, \mathrm{Rb}, \mathrm{Se} \\
\mathrm{B}, \mathrm{Mg}, \mathrm{Co}, \mathrm{Cu}, \mathrm{Zn}, \mathrm{As}, \mathrm{Rb}, \mathrm{Sr}, \mathrm{Mo} \text {, } \\
\mathrm{Cd}, \mathrm{Cs} \text { and } \mathrm{Ba}\end{array}$ & $\begin{array}{l}\text { Concentration in soil and plant } \\
\text { uptake }\end{array}$ & Cheajesadagul et al. (2013) \\
\hline Arros de Valencia & $\begin{array}{l}\text { Japan, India, Tarragona, Brazil, } \\
\text { Murcia, Valencia, Extremadura }\end{array}$ & Yb, Cd, Ti, La, Pr, Er, Ti, Eu, Co & $\begin{array}{l}\text { Soil } \\
\text { Anthropic conditions } \\
\text { Plant uptake }\end{array}$ & Gonzálvez et al. (2011) \\
\hline Taiwan traceability system & $\begin{array}{l}7 \text { districts in } 4 \text { geographic regions in } \\
\text { Taiwan }\end{array}$ & $\begin{array}{l}\mathrm{Ca}, \mathrm{Mg}, \mathrm{K}, \mathrm{P} \\
\mathrm{Fe}, \mathrm{Mn}, \mathrm{Zn}, \mathrm{Cu}\end{array}$ & $\begin{array}{l}\text { Crop management } \\
\text { Soil characteristics }\end{array}$ & Wang et al. (2011) \\
\hline Italian rice & 4 cities in Italy & $\mathrm{K}, \mathrm{Mn}, \mathrm{Fe}$ & & Brandolini et al. (2006) \\
\hline Premium long rice & India, Pakistan, USA, Europe & $\begin{array}{l}\mathrm{Mg}, \mathrm{B} \\
\mathrm{Se} \\
\mathrm{Rb}, \mathrm{Gd}, \mathrm{Ho}, \mathrm{W}\end{array}$ & Soil composition & Kelly et al. (2002) \\
\hline Vietnamese rice & Vietnam, Australia & $\begin{array}{l}\mathrm{P}, \mathrm{K}, \mathrm{Mg}, \mathrm{Ca}, \mathrm{Fe} \text { and } \mathrm{Mn} \\
\mathrm{Zn}, \mathrm{Cu}, \mathrm{Cd} \\
\mathrm{Mn} \text { and } \mathrm{Mo}\end{array}$ & $\begin{array}{l}\text { Fertilizers and soil } \\
\text { composition }\end{array}$ & Kokot and Phuong (1999) \\
\hline
\end{tabular}

suggests the increase of As lead to a correspondent increases on $\mathrm{As}_{\text {org }}$ on Puita rice, which does not seem to affect Irga424 grains.

\subsection{What to traced in rice?}

Brazilian rice has been monitored concerning organic and traditional cultivation systems (Borges et al., 2015), mineral composition and daily intake (Da Silva Iago, Ana, \& da Silva Maria, 2018; Silva \& Ferreira, 2013). Da Silva Iago et al. (2018) discriminated white, parboiled, and brown rice mostly by essential element content. Two rice production regions in Brazil, Goias, and Rio Grande do Sul, were studied in order to classify samples by geographical origin (Maione et al., 2016). Commercially available rice samples from Brazil were used to test geographical traceability of Spanish samples under Protected Geographic Indication (PGI) of "Arros de Valencia" (Gonzálvez et al., 2011). In most of these studies, PCA was used as a reliable tool to group similar samples and to discriminate significant differences that later were linked to location. Some traceability studies used simplified models that derived from PCA data reduction, such as (Kelly et al., 2002) in biplots or radar plots (Cheajesadagul et al., 2013; Chung et al., 2018; Kelly et al., 2002).

Elements capable of discriminating the geographical origin were identified in several studies, as presented in Table 2 . The present study and other authors (Kokot \& Phuong, 1999; Wang et al., 2011) linked the elemental signature to fertilizers (P, K, Mg). Kokot and Phuong (1999) linked high levels of $\mathrm{P}, \mathrm{K}$, and $\mathrm{Mg}$ with sticky rice variety, and to the high content of amylopectin and phytins. Kelly et al. (2002) proposed rice discrimination from USA, Europe, Japan, India, and Pakistan solely by the content of $\mathrm{B}$ and $\mathrm{Mg}$.

By PCA, several elements are modeled in a linear combination of each factor or principal component. The correlation loading is used to adjust the matrix and to show a new distribution of samples in the space. This model accounts for several elements and is quite complex to express. Therefore, most authors (Kelly et al., 2002; Kokot \& Phuong, 1999) search for a simplified model, expressed by a minimal number of elements or variables.

The present work evaluated some simplified 3D plots as presented in the Supplementary material. One of the studied 3D models was based on the 2D model proposed by Kelly et al. (2002). Fig. 3A shows B and Mg scatter plot of Rio Grande do Sul rice samples, where a certain degree of coincidence with European rice was found, mainly due the coincidence of Rio Grande do Sul samples with Spanish rice values. Another 3D model was defined by the rice grain and husk PCA results (Fig. 3B), where better discrimination was found among samples from Rio Grande do Sul.

Pelotas, Santa Vitoria do Palmar, Arroio Grande and Itaqui were the cities with significant number of cases. Therefore, both PCA discriminating model and the 3D simplified model have a higher predictive accuracy to those cities. Herval, Capao do Leao, Jaguarao, and Rio Grande were the cities with few evaluated samples. However, the data from these cities allow testing the discriminating power of the proposed model, as presented in Fig. 3.

Chung et al. (2018) achieved rice geographical discrimination with ${ }^{34} \mathrm{~S}$, Mg, and Mn among Cambodia, China, Japan, Korea, Philippines, and Thailand. However, stable isotopes such as ${ }^{34} \mathrm{~S}$ can suffer undesirable seasonal change (Kelly et al., 2002). However, Mg and Mn seem to fit the model in several studies. Rare earth elements (REEs) like $\mathrm{Yb}, \mathrm{La}, \mathrm{Eu}, \mathrm{Pr}, \mathrm{Er}$ and Gd, Ho provided more specific rice discrimination identified by Gonzálvez et al. (2011) and by Kelly et al. (2002) respectively. REEs occur with phosphoric rocks and suffer low anthropic interference (Chung et al., 2018). The trace content of La and Ce in fertilizers allowed some degree of discrimination on organic and conventional crops (Borges et al., 2015; Rommel et al., 2016). Also, Rb and Cs were considered as useful tracers of agricultural products, as they are ready to be transported from the soil to the plant (Kelly et al., 2002). The As and Cd oppose trend was reported by several authors (Chung et al., 2018; Kokot \& Phuong, 1999). The content of REEs, Cd, As is related to the soil redox potential (Guo et al., 2010). Where REEs and As are more available under reductive conditions and $\mathrm{Cd}$ requires more oxidant environment to be soluble. Table 2 presents a summary of these studies. 


\subsection{How to trace rice in Brazil?}

The present study evaluated samples provided by rice producers from the Rio Grande do Sul. However, no comparison with other discriminated geographical areas was performed. As an exploratory study, the goal was to evaluate analytical and statistical procedures.

In a future traceability study, the seasonal variability, crop management, authentic rice from other countries, and other productive regions in Brazil (Goias, Pará, and other) should be evaluated. A similar number of samples from each city also could provide a more reliable model, with the same predictive capability to all geographical regions (Maione \& Barbosa, 2018).

Due to the complex producing chain, where several farms could adopt different crop management systems and send the rice to different processing and distribution centers, to trace these routes are also required. Particularly important is to identify the crop management procedures adopted by larger producers. As an example, the practices adopted by producer P1 could provide valuable information on Asmitigation in rice.

\subsection{Why trace Brazilian rice?}

Food safety and authenticity has been an increasing concern for many producers and governments. International legislation has been approved in order to establish trade requirements on safety and quality of the products, protecting consumers against fraud and imitation.

In Brazil, the rice market is growing, emerging to the world market. On international trades, frequently As monitoring in rice is mandatory and corresponds to an important step in risk assessment. Due to changes in soil conditions and composition As content suffers variation according to geographical localization and crop management. Geographical discrimination was not previously evaluated among the Rio Grande do Sul producers and cities.

However, the monitoring of nutritional and toxic content in rice involves knowing the whole production chain (origin, storage, and processing of the grains). The farming conditions provide a unique signature that could be linked to a city or a particular producer and its procedures. To initiate rice traceability in Rio Grande do Sul allows identifying strengths and weaknesses in a product to be improved. A step further to provide confidence to Brazilian rice in a very competitive market.

\section{Conclusion}

Considering the first 9 cities and 17 producers in the present work, three cities had enough data to allow rice traceability. PCA proved to be a useful tool to perform data reduction and to identify the main parameters that could explain rice variability among cities. Pelotas, Arroio Grande, Itaqui and Santa Vitoria do Palmar presented a remarkable degree of discrimination based on the elemental content in rice grain and husk. One particular producer from Pelotas was individually discriminated from remaining cities and producers. Even though with a smaller number of samples, the discrimination between other geographical areas is promising by using husk variables. Especially when considering the cities in Rio Grande do Sul were in the same geological formation with no significant soil differences. The soil redox conditions have affected the rice and husk elemental content. Therefore, in future studies, the elemental and isotopic measurement of REEs could help to provide a more robust dataset for traceability.

\section{Funding}

This work was supported by Fundação de Amparo a Pesquisa do Estado de São Paulo (grants number 2014/05151-0, 2016-10060-9, 2017/20914-8 and 2018/21494-5) and by the Conselho Nacional de Desenvolvimento Científico e Tecnológico, Brazil (grant number
$444280 / 2014-6)$

\section{Availability of data and materials}

All data supporting the conclusions of this article are provided as figures, tables, and supplementary tables and figures.

\section{Authors' contributions}

Camila Neves Lange - analysis and manuscript writing; Lucilena Rebelo Monteiro - statistical analysis and manuscript writing; Bruna Moreira Freire - rice analysis and manuscript writing; Daniel Fernandez Franco - seeds sampling and manuscript writing; Rogério Oliveira de Sousa - soil sampling, analysis and manuscript writing; Cecília Sacramento dos Reis Ferreira - soil sampling, analysis and manuscript writing; Julio José Centeno da Silva - rice analysis and manuscript writing; Bruno Lemos Batista - soil/rice analysis, and manuscript writing and revision.

\section{Ethics approval and consent to participate}

Not applicable.

\section{Consent for publication}

Not applicable.

\section{Declaration of Competing Interest}

The authors declare that they have no competing interests.

\section{Acknowledgments}

We are thankful to Fundação de Amparo a Pesquisa do Estado de São Paulo and to the Conselho Nacional de Desenvolvimento Científico e Tecnológico.

\section{Appendix A. Supplementary data}

Supplementary data to this article can be found online at https:// doi.org/10.1016/j.foodchem.2019.125145.

\section{References}

Agrama, H., \& Yan, W. (2009). Association mapping of straighthead disorder induced by arsenic in Oryza sativa. Plant Breeding, 128(6), 551-558.

Alloway, B. J. (2008). Zinc in soils and crop nutrition. Brussels, Belgium: International Zinc Association.

Althaus, D., Gianello, C., Tedesco, M. J., da Silva, K. J., Bissani, C. A \& \& Felisberto, R (2018). Natural fertility and metals contents in Soils of Rio Grande do Sul (Brazil). Revista Brasileira de Ciencia do Solo, 42.

ANVISA (2013). Resolução-RDC n.42, de 29 de Agosto de 2013.

Arisseto-Bragotto, A. P., Feltes, M. M. C., \& Block, J. M. (2017). Food quality and safety progress in the Brazilian food and beverage industry: Chemical hazards. Food Quality and Safety, 1(2), 117-129.

Barbosa, R. M., de Paula, E. S., Paulelli, A. C., Moore, A. F., Souza, J. M. O., Batista, B. L., Barbosa, F., Jr. (2016). Recognition of organic rice samples based on trace elements and support vector machines. Journal of Food Composition and Analysis, 45, 95-100.

Batista, B. L., Souza, J. M. O., Souza, S. S. D., \& Barbosa, F. (2011). Speciation of arsenic in rice and estimation of daily intake of different arsenic species by Brazilians through rice consumption. Journal of Hazardous Materials, 191(1-3), 342-348.

Bini, C., Nadimi-Goki, M., Kato, Y., Vianello, G., Antisari, L. V., Wahsha, M., \& Spiandorello, M. (2014). Assessment of total soil and plant elements in rice-based production systems in NE Italy. European Geosciences Union General Assembly, Vienna (pp. 147). .

Borges, E. M., Gelinsky, J., Souza, V. C. O., Barbosa, F., Jr., \& Batista, B. L. (2015). Monitoring the authenticity of organic rice via chemometric analysis of elemental data. Food Research International, 77, 299-309.

Brandolini, V., Coisson, J. D., Tedeschi, P., Barile, D., Vecchiati, G., Martelli, A., \& Arlorio, M. (2006). Chemometrical characterization of four Italian rice varieties based on genetic and chemical analyses. Journal of. Agriculture and Food Chemistry, 54(26), 
9985-9991.

Bro, R., \& Smilde, A. (2014). Principal component analysis. Analytical Methods, 6(9), 2812-2831.

Callao, M. P., \& Ruisánchez, I. (2018). An overview of multivariate qualitative methods for food fraud detection. Food Control, 86, 283-293.

Cheajesadagul, P., Arnaudguilhem, C., Shiowatana, J., Siripinyanond, A., \& Szpunar, J. (2013). Discrimination of geographical origin of rice based on multi-element fingerprinting by high resolution inductively coupled plasma mass spectrometry. Food Chemistry, 141, 3504-3509.

Chung, I. M., Kim, J. K., Lee, J. K., \& Kim, S. H. (2015). Discrimination of geographical origin of rice (Oryza sativa L.) by multielement analysis using inductively coupled plasma atomic emission spectroscopy and multivariate analysis. Journal of Cereal Science, 65, 252-259.

Chung, I. M., Kim, J. K., Lee, K. J., Park, S. K., Lee, J. H., Son, N. Y., ... Kim, S. H. (2018). Geographic authentication of Asian rice (Oryza sativa L.) using multi-elemental and stable isotopic data combined with multivariate analysis. Food Chemistry, 240, 840-849.

Commission, C. A. (2016). Report of the 10th session of the codex committee on contaminants in foods, Rotterdam, The Netherlands, 4-8 April 2016. 39th Session Rome, Italy.

Da Silva Iago, J. S., Ana, P. S. P., \& da Silva Maria, J. (2018). Composition and estimate of daily mineral intake from samples of Brazilian rice. Microchemical Journal, 137, $131-138$.

FAO (2018). FAO rice market monitor (RMM), Vol. XXI, Issue No. 1 XXI(1).

Fink, J. R., Inda, A. V., Tiecher, T., \& Barrón, V. (2016). Iron oxides and organic matter on soil phosphorus availability. Ciência e agrotecnologia, 40(4), 369-379.

Gonzálvez, A., Armenta, S., \& Guardia, M. D. L. (2011). Geographical traceability of "arros de Valencia" rice grain based on mineral element composition. Food Chemistry, 126, 1254-1260.

Guo, H., Zhang, B., Wang, G., \& Shen, Z. (2010). Geochemical controls on arsenic and rare earth elements approximately along a groundwater flow path in the shallow aquifer of the Hetao Basin, Inner Mongolia. Chemical Geology, 270(1-4), 117-125.

IBGE (2017). Instituto Brasileiro de Geografia e Estatística. Estatísticas Econômicas.

John, S. R. (2007). The mobility and bioavailability of trace metals in tropical soils: A review. Chemical Speciation \& Bioavailability, 19(2), 75-85.

Kato, L. S., Fernandes, E. A. D. N., Bacchi, M. A., \& Sarriés, G. A. (2018). Elemental composition of Brazilian rice grains from different cultivars and origins. Journal Radioanalytical Nuclear Chemistry, 318, 745-751.

Kelly, S., Baxter, M., Chapman, S., Rhodes, C., Dennis, J., \& Brereton, P. (2002). The application of isotopic and elemental analysis to determine the geographical origin of premium long grain rice. European Food Research and Technology, 214, 72-78.

Kokot, S., \& Phuong, T. D. (1999). Elemental content of Vietnamese rice Part 2. Multivariate data analysis. Analyst, 4, 561-569.

Kukusamude, C., \& Kongsri, S. (2018). Elemental and isotopic profiling of Thai jasmine rice (Khao Dawk Mali 105) for discrimination of geographical origins in Thung Kula Rong Hai area, Thailand. Food Control, 91, 357-364.

Kumarathilaka, P., Seneweera, S., Bundschuh, J., \& Meharg, A. (2018). Arsenic accumulation in rice (Oryza sativa L.) is influenced by environment and genetic factors. Science of the Total Environment, 642, 485-496.

Maione, C., \& Barbosa, R. M. (2018). Recent applications of multivariate data analysis methods in authentication of rice and the most analyzed parameters: A Review. Critical Reviews in Food Science and Nutrition. https://doi.org/10.1080/10408398. 2018.1431763.

Maione, C., Batista, B., Campiglia, A., Barbosa, F., \& Barbosa, R. M. (2016). Classification of geographic origin of rice by data mining and inductively coupled plasma mass spectrometry. Computers and Electronics in Agriculture, 121, 101-107.

Paniz, F. P., Pedron, T., Freire, B. M., Torres, D. P., Silva, F. F., \& Batista, B. L. (2018) Effective procedures for the determination of $\mathrm{As}, \mathrm{Cd}, \mathrm{Cu}, \mathrm{Fe}, \mathrm{Hg}, \mathrm{Mg}, \mathrm{Mn}, \mathrm{Ni}, \mathrm{Pb}, \mathrm{Se}$, Th, Zn, U and rare earth elements in plants and foodstuffs. Anaytical Methods, 10, 4094-4103.

Rommel, M. B., de Paula Eloisa, S., Ana, C. P., Anthony, F. M., Juliana, M. O. S., Bruno, L. B., ... Fernando, B. (2016). Recognition of organic rice samples based on trace elements and support vector machines. Journal of Food Composition and Analysis, 45, 95-100.

Segura, F. R., Nunes, E. A., Paniz, F. P., Paulelli, A. C. C., Rodrigues, G. B., Úbida Leite Braga, G., ... Batista, B. L. (2016). Potential risks of the residue from Samarco's mine dam burst (Bento Rodrigues, Brazil). Environmental Pollution, 218, 813-825.

Silva, E., \& Ferreira, S. (2013). Determination of the mineral composition of Brazilian rice and evaluation using chemometric techniques. Analytical Methods, 5, 998-1003.

SOSBAI (2010). ARROZ IRRIGADO: Recomendações Técnicas da Pesquisa para o Sul do Brasil. XXVIII REUNIÃO TÉCNICA DA CULTURA DO ARROZ IRRIGADO (pp. 188). SOSBAI - Sociedade Sul-Brasileira de Arroz Irrigado.

Suda, A., \& Makino, T. (2016). Functional effects of manganese and iron oxides on the dynamics of trace elements in soils with a special focus on arsenic and cadmium: A review. Geoderma, 270(C), 68-75.

Tedesco, M., Gianello, C., Bissani, C., Bohnen, H., \& Volkweiss, S. (1995). Análises de solo, plantas e outros materiais. UFRGS.

Tuli, R., Chakrabarty, D., Trivedi, P., \& Tripathi, R. (2010). Recent advances in arsenic accumulation and metabolism in rice. Molecular Breeding, 26(2), 307-323.

USEPA (2007). Method 3051A (SW-846): Microwave assisted acid digestion of sediments, sludges, and oils. Revision 1. Washington, DC.

Wang, I. C., Hsu, R. J. C., \& Lu, S. (2011). Rice traceability system in Taiwan. Quality Assurance and Safety of Crops \& Foods, 3(2), 74-81.

Yamaguchi, N., Ohkura, T., Takahashi, Y., Maejima, Y., \& Arao, T. (2014). Arsenic distribution and speciation near rice roots influenced by iron plaques and redox conditions of the soil matrix. Environmental Science \& Technology, 48(3), 1549-1556. 